\title{
Yield and feeding of prairie grasses in east-central Alberta
}

\author{
ABDULLATIF SULEIMAN, ERASMUS K. OKINE, LAKSIRI A. GOONEWARDENE, PHYLLIS. A. DAY, BARRY \\ YAREMCIO AND GUILLERMO RECINOS-DIAZ
}

Animal Industry Division, Alberta Agriculture, Food and Rural Development, \# 204, 7000-113 Street, Edmonton, Alberta, Canada T6H 5T6. Author position titles: A. Suleiman: laboratory nutritionist; E. K. Okine: ruminant nutritionist; L. A. Goonewardene: manager, Research Support Group; P.

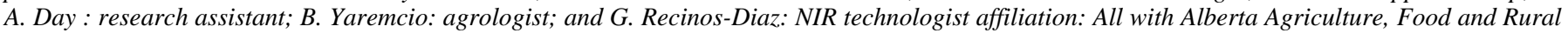
Development (AAFRD).

\section{Abstract}

Information on the yield of grasses as the plants mature is useful to optimize grazing potential and quality hay production. The objectives of this study were to compare the yield and feeding value of 11 common prairie grasses over 2 yearly cycles of growth and determine which of the grasses may require supplementation to meet nutrient requirements of grazing cattle. Dry matter yield (DM), crude protein (CP), acid detergent fiber (ADF), calcium (Ca), and phosphorus (P) values were obtained for brome (Bromus inermis [L.]), creeping red fescue (Festuca rubra [L.]), crested wheatgrass (Agropyron cristatum [L.] Gaertn), intermediate wheatgrass (Agropyron intermedium (host) Beauv), meadow foxtail (Alopecurus pratensis [L.]), orchardgrass (Dactylis glomerata [L.]), pubescent wheatgrass (Agropyron trichophorum Link. richt), streambank wheatgrass (Agropyron riparium Scriba \& Smith), slender wheatgrass (Agropyron trachycaulum Link Malte), tall fescue (Festuca arundinacea Schreb), and timothy (Phleum pratense [L.]) at weekly intervals from June to September, in 1992 and 1993. Most grasses reached maximum yields at week 8 in 1992 (drought year) and week 12 in 1993 (normal year). Herbage mass yields $\left(\mathrm{g} / 0.25 \mathrm{~m}^{2}\right)$ at week 8 in 1992 (highest to lowest yielding) were crested wheatgrass (235), intermediate wheatgrass $(210)$, pubescent wheatgrass(173), brome(161), slender wheatgrass(152), meadow foxtail(114), Tall fescue(110), timothy(101), orchardgrass(83), creeping red fescue (56), and streambank wheatgrass $(50)$. Herbage mass yields pattern of the grasses in 1993 was similar to that in 1992 except for crested wheatgrass and brome which ranked first and fourth in 1992 but ranked fifth and second, in 1993, respectively. Quality declined in all grasses as they matured. The average CP content of grasses declined from $24 \%$ to $13 \%$ in 1992 and from $21.5 \%$ to $12.1 \%$ in 1993 but were adequate to meet crude protein requirements of growing, pregnant or lactating grazing cattle. The Ca levels in all grasses were adequate for all classes of cattle on pasture but the low $P$ levels of $0.11 \%$ in both years indicate that growing, pregnant or lactating cattle grazing on these pastures would require $\mathbf{P}$ supplementation.

Key Words: yield, feeding value, prairie grasses, nutrient composition

Manuscipt accepted 18 April 1998.

\section{Resumen}

La información sobre el rendimiento de los pastos conforme las plantas maduran es útil para optimizar el potencial de pastoreo y la producción de heno de calidad. Los objetivos de este estudio fueron comparar el rendimiento y valor nutritivo de 11 pastos comunes de la pradera durante 2 ciclos de crecimiento y determinar cuál de los pastos puede requerir suplementación para satisfacer los requerimientos nutricionales del ganado en pastoreo. Los valores de rendimiento de materia seca (DM), proteína cruda (CP), fibra ácido detergente, calcio y fósforo fueron determinados semanalmente de junio a septiembre de 1992 y 1993 en los pastos "brome" (Bromus inermis [L.]), "creeping red fescue" (Festuca ruba [L.]), "crested wheatgrass" (Agropyron cristatum [L.] Gaertn), "intermediate wheatgrass" (Agropyron intermedium (Host) Beauv), "meadow foxtail" (Alopecurus pratensis [L.]), "orchardgrass" (Dactylis glomerata [L.]), "pubescent wheatgrass" (Agropyron trichophorum Link. richt), "streambank wheatgrass (Agropyron riparium Scriba y Smith), "slender wheatgrass" (Agropyron trachycaulum Link Malte ), "Tall fescue" (Festuca arundinacea Schreb ) "timothy" (Phleum pratense [L.]). En 1992 (año seco) la mayoría de los pastos alcanzó su máximo rendimiento en la semana 8 y en 1993 (año normal) en la semana 12. En 1992 el rendimiento de forraje $\left(\mathrm{g} / 0.25 \mathrm{~m}^{2}\right)$ en la semana 8 (ordenados de mayor a menor) fue $235,210,173,161,152,114,110,101,83,56$ y 50 g para "crested wheatgrass", "intermediate wheatgrass", "pubescent wheatgrass", "brome", "slender wheatgrass", "meadow foxtail", "tall fescue", "timothy"," orchardgrass", "creeping red fescue", $y$ " streambank wheatgrass" respectivamente. En 1993 el patrón de rendimiento de forraje fue similar al de 1992 excepto para "crested wheatgrass" y "brome" los cuales clasificaron en primero y cuarto lugar en 1992 y en quinto y segundo lugar en 1993; respectivamente. La calidad de todos los pastos declinó conforme maduraron. El promedio de proteína cruda disminuyó de $24 \%$ a $13 \%$ en 1992 y de $21.5 \%$ a 12.1\% en 1993; sin embargo, el contenido de proteína cruda fue suficiente para satisfacer los requerimientos del ganado en pastoreo en las etapas de crecimento, lactancia y preñez. Los niveles de calcio de todos los pastos fueron adecuados para todas las clases de ganado en pastoreo. Los bajos niveles de fósforo $(0.11 \%)$ en ambos años indican que ganado en crecimiento, lactancia y preñez que pastore estas praderas requerira suplementación de fósforo. 
Traditional methods of open range grazing are being replaced with high intensity rotational grazing systems because of economic constraints such as the cost of land (Smith 1981). Thus, cattle producers continue to modify management practices such as cutting and grazing to optimize productivity and profitability from limited land bases. In addition, rates of gain of cattle in some grazing trials have been comparable to those achieved in feedlots in Alberta but at a much lower cost per kilogram of gain (McCaughey and Cliplef 1996). However, little information is available comparing grass species for high intensity range hay production in Alberta. Information on yields of herbage mass and changes in quality as the plant matures would help evaluate the potential of grass species for hay or grazing over an extended grazing season. The parkland area of the prairies cuts across Central Alberta which is also an area where beef enterprises are highly concentrated (Baron and Knowles 1984).

Increasingly, near infrared reflectance spectroscopy (NIRS) is being used to determine composition of feedstuffs including the determination of several proximate analysis parameters that usually are obtained by wet chemistry methods. Information on the applicability of NIRS in the analysis of growing forages would be useful since it would permit obtaining nutrient profiles of pastures. This technology has been shown to be reliable in proximate analysis (Shenk and Westerhaus 1994, Shenk 1989, Redshaw et al. 1986).

The objectives of this study were to compare the yield and quality of common prairie grasses over 2 years and to determine which grasses are ade- quate to meet nutrient requirements of all classes of grazing cattle. A second objective of the study was to evaluate the use of NIRS technology to predict nutrient composition of these grasses and test the accuracy of the calibrations developed.

\section{Materials and Methods}

Eleven pure cultivated stands of prairie grasses, brome (Bromus inermis [L.]), creeping red fescue (Festuca rubra [L.]), crested wheatgrass (Agropyron cristatum [L.] Gaertn.), intermediate wheatgrass (Agropyron intermedium (host) Beauv), meadow foxtail (Alopecurus pratensis [L.]), orchardgrass (Dactylis glomerata [L.]), pubescent wheatgrass (Agropyron trichophorum Link. richt), streambank wheatgrass (Agropyron riparium Scriba \& Smith), slender wheatgrass (Agropyron trachycaulum Link Malte), tall fescue (Festuca arundinacea Schreb), and timothy (Phleum pratense [L.]) were used in 1992 in three, $16 \times 12 \mathrm{~m}^{2}$ replicated plots at the Alberta Agriculture, Tree Nursery and Horticulture Centre, Edmonton, Alberta, Canada. Each grass was randomly replicated in 3 different blocks. The plots were located in the Black soil zone in east-central Alberta. The soil was a Ponoka Light Loam (lacustrine, medium textured) (Bowser et al. 1962). The topography is level to undulating and the soil is found on the edge of basinlike areas, that is, on the edge of lacustrine basins. Based on soil fertility tests, only nitrogen was applied across the plots in the spring of 1992 at a rate of $34 \mathrm{~kg} \mathrm{ha}^{-1}$.

Samples consisted of weekly clippings from the 3 plots. The treatments were arranged in a multiway randomized block design with 3 replicates. Once randomized, the plot area remained unchanged. Subsamples were clipped to a stubble height of 3 $\mathrm{cm}$ with hand-held sheep shears from three $0.25 \mathrm{~m}^{2}$ areas of each plot per week. Adjacent $0.25 \mathrm{~m}^{2}$ areas of grass stands were sampled at each clipping to obtain cumulative herbage mass. In 1992, first clippings were taken on 15 June. After the last samples were taken in second week of August all plots were clipped to a stubble height of $7.5 \mathrm{~cm}$ using a gas-powered garden mower. The study was repeated in 1993, however, the first samples were taken on 21 June and the last samples in early September.

All individual forage subsamples were weighed prior to drying and were then oven dried at $60^{\circ} \mathrm{C}$ for 24 hours, re-weighed, and ground through a 1mm screen (Wiley mill, Standard model 3, Arthur H. Thomas Co., Philadelphia, Penn). Crude protein (CP), calcium (Ca) and phosphorus (P) were measured colorimetrically with a Technicon Auto Analyzer II method in which samples had been prepared using the Kjeldahl digestion (method no. 7.022) according to standard procedures (AOAC 1990) and acid detergent fiber (ADF) was determined by the method of Goering and Van Soest (1970). The wet chemistry values obtained on 1992 pasture samples, corrected for dry matter (DM) content at $104^{\circ} \mathrm{C}$ (method no. 7.003, AOAC 1990), were used to develop NIRS regression equations to predict $\mathrm{DM}, \mathrm{CP}, \mathrm{ADF}, \mathrm{Ca}$, and $\mathrm{P}$ in the grasses.

Samples obtained in 1993 were scanned by the NIR system model 6500 instrument (NIR System, Inc., Silver Spring, Md), and the spectra

\begin{tabular}{|c|c|c|c|c|c|c|c|c|c|c|c|c|}
\hline \multirow[b]{2}{*}{ Nutrient } & \multicolumn{4}{|c|}{1992} & \multicolumn{3}{|c|}{1993} & \multicolumn{4}{|c|}{1992 and 1993 combined } & \multirow[b]{2}{*}{ Slope } \\
\hline & $\mathrm{N}$ & $r^{2}$ & SEC & Slope & $\mathrm{N}$ & $r^{2}$ & SEC & Slope & $\mathrm{N}$ & $\mathrm{r}^{2}$ & SEC & \\
\hline $\mathrm{DM}$ & 176 & 0.99 & 0.06 & 0.98 & 206 & 0.95 & 0.13 & 0.95 & 386 & 1.00 & 0.08 & 1.00 \\
\hline $\mathrm{CP}$ & 173 & 0.99 & 0.37 & 0.99 & 203 & 0.99 & 0.44 & 0.99 & 387 & 0.99 & 0.46 & 0.99 \\
\hline $\mathrm{Ca}$ & 177 & 0.60 & 0.05 & 0.44 & 207 & 0.72 & 0.04 & 0.59 & 389 & 0.59 & 0.05 & 0.53 \\
\hline $\mathrm{P}$ & 181 & 0.93 & 0.01 & 0.90 & 204 & 0.94 & 0.02 & 0.90 & 389 & 0.90 & 0.02 & 0.88 \\
\hline ADF & 176 & 0.98 & 0.69 & 0.98 & 176 & 0.98 & 0.60 & 0.95 & 392 & 0.98 & 0.61 & 0.98 \\
\hline
\end{tabular}




\begin{tabular}{|c|c|c|c|c|c|c|c|}
\hline \multirow[b]{2}{*}{ Pasture $^{2}$} & \multicolumn{7}{|c|}{$\begin{array}{c}\text { Week of Cut } \\
\text { Herbage mass }\end{array}$} \\
\hline & 2 & 4 & 5 & 6 & 7 & 8 & 10 \\
\hline \\
\hline BR & $18.5^{\mathrm{bc}}$ & $44.9^{\text {cde }}$ & $76.1^{\mathrm{ab}}$ & $100.3^{\mathrm{abc}}$ & $116.8^{\mathrm{abc}}$ & $161.2^{\mathrm{b}}$ & $148.5^{\mathrm{bc}}$ \\
\hline CRF & $9.1^{\mathrm{c}}$ & $23.1^{\mathrm{f}}$ & $35.5^{\mathrm{c}}$ & $53.4^{\mathrm{bc}}$ & $60.9^{c}$ & $56.2^{\mathrm{d}}$ & $47.5^{\mathrm{f}}$ \\
\hline CRWG & $38.4^{\mathrm{a}}$ & $81.7^{\mathrm{a}}$ & $105.1^{\mathrm{a}}$ & $129.2^{\mathrm{a}}$ & $112.0^{\mathrm{abc}}$ & $235.4^{\mathrm{a}}$ & $118.7^{\text {cde }}$ \\
\hline IWG & $26.9^{\mathrm{b}}$ & $54.8^{\mathrm{c}}$ & $89.9^{\mathrm{ab}}$ & $109.1^{\mathrm{abc}}$ & $122.4^{\mathrm{abc}}$ & $210.7^{\mathrm{a}}$ & $196.0^{\mathrm{a}}$ \\
\hline MFT & $40.7^{\mathrm{a}}$ & $67.7^{\mathrm{b}}$ & $83.5^{\mathrm{ab}}$ & $89.0^{\mathrm{abc}}$ & $101.4^{\mathrm{abc}}$ & $114.4^{\mathrm{c}}$ & $60.1^{\mathrm{f}}$ \\
\hline OCHG & $15.4^{\mathrm{bc}}$ & $32.7^{\mathrm{ef}}$ & $52.1^{\mathrm{bc}}$ & $68.8^{\mathrm{abc}}$ & $127.5^{\mathrm{abc}}$ & $83.2^{\mathrm{cd}}$ & $69.9^{\mathrm{f}}$ \\
\hline PWG & $19.2^{\mathrm{bc}}$ & $41.9^{\text {cde }}$ & $79.3^{\mathrm{ab}}$ & $125.3^{\mathrm{ab}}$ & $175.5^{\mathrm{a}}$ & $173.3^{\mathrm{b}}$ & $170.0^{\mathrm{ab}}$ \\
\hline STWG & $11.4^{\mathrm{c}}$ & $26.7^{\mathrm{f}}$ & $28.8^{\mathrm{c}}$ & $43.1^{\mathrm{c}}$ & $54.4^{\mathrm{c}}$ & $50.0^{\mathrm{d}}$ & $50.3^{\mathrm{f}}$ \\
\hline SWG & $21.7^{\mathrm{bc}}$ & $48.4^{\mathrm{cd}}$ & $75.4^{\mathrm{ab}}$ & $105.0^{\mathrm{abc}}$ & $144.9^{\mathrm{ab}}$ & $152.1^{\mathrm{b}}$ & $132.2^{\text {bcd }}$ \\
\hline $\mathrm{TF}$ & $16.7^{\mathrm{bc}}$ & $30.9^{\mathrm{ef}}$ & $54.0^{\mathrm{bc}}$ & $80.2^{\mathrm{abc}}$ & $80.2^{\mathrm{bc}}$ & $109.8^{\mathrm{c}}$ & $93.5^{\text {def }}$ \\
\hline TIM & $12.7^{\mathrm{c}}$ & $34.7^{\mathrm{def}}$ & $59.1^{\mathrm{bc}}$ & $77.8^{\mathrm{abc}}$ & $86.5^{\mathrm{bc}}$ & $101.4^{\mathrm{c}}$ & $85.7^{\mathrm{ef}}$ \\
\hline SEM & 2.9 & 3.6 & 8.3 & 14.9 & 16.1 & 11.6 & 10.8 \\
\hline
\end{tabular}

collected as $\log (1 / \mathrm{R})$ from $400 \mathrm{~nm}$ to 2,498 nm. All 1993 samples were scanned and samples that differed spectrally (from 1992 samples) were added to the 1992 calibration set. The combined sample spectra were used to develop new calibration regressions. Four hundred and two samples (Table 1) from the 2 year combined total of 1,782 samples, across different stages of growth, were selected using the Center, Select and Cal programs developed by Intrasoft International NIRS2 software, version 3.0 (NIRSystem, Inc., Silver Spring, Md.,
Shenk and Westerhaus 1991a) for calibration and validation. The total of 402 samples was made up of 187 samples selected from 693 samples in 1992 and 215 samples selected from 1,089 samples in 1993 (Table 1). The NIRS calibrations were obtained using 4 cross validation groups with modified partial least squares analysis using every eighth wavelength between 400 and 2,498 $\mathrm{nm}$. The critical math treatment was $3,5,5,1$ calculated with a difference of 5 data points followed by a 5 point smooth. Detrend (NIRSystem, Inc., Silver
Spring, Md., Shenk and Westerhaus 1991b) was used to reduce the interference of light scatter and particle size of sample in the spectra. Downweight was used to remove samples with large $\mathrm{T}$ or $\mathrm{H}$ values. Spectral distance calculations, selection of samples and calibration regressions were carried out by the Center, Select and $\mathrm{Cal}$ programs developed by Intrasoft International NIRS2 software, version 3.0 (NIRSystem, Inc., Silver Spring, Md., Shenk and Westerhaus 1991c). The Center program was used to order all samples according to $\mathrm{H}$ Mahalanobis distance and to remove or discriminate outlier samples with a cut-off distance of global H > 3.0 (Shenk and Westerhaus 1994). Accuracy of the new regression equations to predict the nutrient content of grasses was evaluated by comparing the predicted nutrient values with wet chemistry values of the samples in the calibration set.

The data were analyzed using General Linear Model (GLM) procedure of SAS (1990). Experimental design was a randomized block with 3 replicates per treatment. The data of each grass from the blocks were compared for quantity and quality of dry matter. Means when significant were separated by a student Newman Keul's test (SAS 1990). Significance was declared at $\mathrm{P} \leq 0.05$ unless specified otherwise.

Table 3. Average herbage mass ${ }^{1}$ of pasture species at different weeks in 1993.

\begin{tabular}{|c|c|c|c|c|c|c|c|c|c|c|c|}
\hline \multirow[b]{2}{*}{ PASTURE $^{2}$} & \multicolumn{10}{|c|}{ Week of cut } & \multirow[b]{2}{*}{14} \\
\hline & 3 & 5 & 6 & 7 & 8 & 9 & 10 & 11 & 12 & 13 & \\
\hline & & & & & ------_—- & $\left.0.25 \mathrm{~m}^{2}\right)$ & & & & & \\
\hline BR & $53.9^{\mathrm{bc}}$ & $103.8^{\mathrm{a}}$ & $135.5^{\mathrm{a}}$ & $191.8^{\mathrm{a}}$ & $216.0^{\mathrm{a}}$ & $259.7^{\mathrm{a}}$ & $225.7^{\mathrm{abc}}$ & $302.4^{\mathrm{abc}}$ & $416.2^{\mathrm{ab}}$ & $331.0^{\mathrm{ab}}$ & $282.6^{\mathrm{abc}}$ \\
\hline CRWG & $57.9^{\mathrm{b}}$ & $111.5^{\mathrm{a}}$ & $146.7^{\mathrm{a}}$ & $199.9^{\mathrm{a}}$ & $207.5^{\mathrm{a}}$ & $224.4^{\mathrm{ab}}$ & $229.0^{\mathrm{abc}}$ & $269.1^{\mathrm{abcd}}$ & $341.1^{\mathrm{bc}}$ & $249.8^{\mathrm{ab}}$ & $243.2^{\mathrm{bc}}$ \\
\hline IWG & $35.1^{\text {cde }}$ & $93.4^{\mathrm{a}}$ & $135.4^{\mathrm{ab}}$ & $215.6^{\mathrm{a}}$ & $222.4^{\mathrm{a}}$ & $257.9^{\mathrm{a}}$ & $253.7 \mathrm{ab}$ & $357.9^{\mathrm{a}}$ & $469.5^{\mathrm{a}}$ & $393.2^{\mathrm{a}}$ & $359.3^{\mathrm{a}}$ \\
\hline MFT & $82.8^{\mathrm{a}}$ & $104.2^{\mathrm{a}}$ & $119.1^{\mathrm{ab}}$ & $126.8^{\mathrm{bc}}$ & $102.9^{c}$ & $107.4^{\mathrm{b}}$ & $109.3^{\mathrm{c}}$ & $164.0^{\mathrm{ef}}$ & $218.5^{\mathrm{d}}$ & $167.3^{\mathrm{ab}}$ & $140.1^{\mathrm{d}}$ \\
\hline STWG & $41.8^{\text {bcde }}$ & $71.4^{\mathrm{a}}$ & $68.9^{\mathrm{b}}$ & $83.8^{\mathrm{c}}$ & $103.2^{\mathrm{c}}$ & $113.8^{\mathrm{b}}$ & $147.9^{\mathrm{bc}}$ & $173.2^{\text {def }}$ & $272.2^{\mathrm{cd}}$ & $197.2^{\mathrm{ab}}$ & $231.1^{\mathrm{bcc}}$ \\
\hline SWG & $32.7^{\mathrm{de}}$ & $71.4^{\mathrm{a}}$ & $92.1^{\mathrm{ab}}$ & $121.4^{\mathrm{bc}}$ & $159.0^{\mathrm{abc}}$ & $171.0^{\mathrm{ab}}$ & $241.3^{\mathrm{abc}}$ & $290.0^{\mathrm{abc}}$ & $372.3^{\mathrm{b}}$ & $293.2^{\mathrm{ab}}$ & $332.1^{\mathrm{ab}}$ \\
\hline $\mathrm{TF}$ & $30.6^{\mathrm{de}}$ & $65.5^{\mathrm{a}}$ & $86.5^{\mathrm{ab}}$ & $96.0^{\mathrm{c}}$ & $95.1^{\mathrm{c}}$ & $171.8^{\mathrm{ab}}$ & $214.9^{\mathrm{abc}}$ & $257.1^{\text {bcde }}$ & $323.7^{\mathrm{bc}}$ & $253.9^{\mathrm{ab}}$ & $321.2^{\mathrm{ab}}$ \\
\hline TIM & $41.0^{\mathrm{bcde}}$ & $84.2^{\mathrm{a}}$ & $82.0^{\mathrm{ab}}$ & $103.9^{c}$ & $112.4^{\mathrm{c}}$ & $107.0^{\mathrm{b}}$ & $132.0^{\mathrm{bc}}$ & $147.7^{\mathrm{f}}$ & $221.9^{\mathrm{d}}$ & $180.3^{\mathrm{ab}}$ & $167.3^{\mathrm{d}}$ \\
\hline SEM & 4.828 & 11.490 & 14.941 & 10.390 & 20.740 & 28.091 & 26.925 & 21.866 & 20.776 & 44.974 & 25.586 \\
\hline
\end{tabular}

Herbage mass (DM yield).

${ }^{2} \mathrm{BR}=$ brome, $\mathrm{CRF}=$ creeping red fescue, $\mathrm{CRWG}=$ crested wheatgrass, $\mathrm{IWG}=$ intermediate wheatgrass, $\mathrm{MFT}=$ meadow foxtail, $\mathrm{OCHG}=$ orchardgrass,

$\mathrm{PWG}=$ pubescent wheatgrass, $\mathrm{STWG}=$ streambank wheatgrass, $\mathrm{SWG}=$ slender wheatgrass, $\mathrm{TF}=$ tall fescue, $\mathrm{TIM}=$ timothy.

Column values with different superscripts are significantly different, $\mathrm{p}<0.05$. 


\begin{tabular}{|c|c|c|c|c|c|c|}
\hline \multirow[b]{2}{*}{ Month } & \multicolumn{3}{|c|}{ Mean Daily Temperature } & \multicolumn{3}{|c|}{ Monthly Precipitation } \\
\hline & 1992 & 1993 & $\begin{array}{c}23 \text { Year } \\
\text { Average* }\end{array}$ & 1992 & 1993 & $\begin{array}{r}23 \text { Year } \\
\text { Average }\end{array}$ \\
\hline \multirow[b]{2}{*}{ May } & & $\left({ }^{\circ} \mathrm{C}\right)$ & 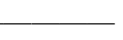 & 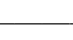 & $\mathrm{nm})$ & - \\
\hline & 9.8 & 12.3 & 11.1 & 33.3 & 51.2 & 49.2 \\
\hline June & 16.0 & 13.9 & 14.9 & 21.8 & 77.3 & 93.6 \\
\hline July & 15.3 & 15.3 & 16.7 & 40.7 & 61.9 & 91.7 \\
\hline August & 14.2 & 15.1 & 15.6 & 35.4 & 78.5 & 68.2 \\
\hline
\end{tabular}

\section{Results and Discussion}

\section{Dry Matter Yield}

Tables 2 and 3 show the pattern of average herbage mass yield of grasses by pasture type and week of cut. The general growth pattern of all grasses, as indicated by herbage mass yield at each weekly cut, were similar. The cumulative herbage mass yields generally increased steadily until a maximum level was reached except for crested wheatgrass in 1992 and brome in 1993, both of which showed a decrease in yield of $13 \%$ before attaining a maximum. This may be due to a transient adverse effect of low precipitation (Table 1) on growth of crested wheatgrass in 1992. The reasons for the decreased herbage mass yield for brome are not readily apparent. All grasses in 1992 reached maximum yields at week 8 with the exception of creeping red fescue, orchardgrass and streambank wheatgrass which appeared to mature or peak earlier at week 7. Early maturity or low yield exhibited by these 3 grasses may be due to sensitivity of creeping red fescue and orchardgrass to lack of adequate moisture and the naturally low forage yield of streambank wheatgrass, considered the lowest yielding cultivated wheatgrass (Smoliak and Bjorge 1981). The longer, more normal, growing season with adequate precipitation in 1993 (Table 4), produced maximum herbage mass yields much later, at week 12, for all grasses (Table 3).

Based on data from both years, the 5 highest yielding grasses were intermediate wheatgrass, brome, crested wheatgrass, pubescent wheatgrass and slender wheatgrass. The 1993 herbage mass yields (in tons per hectare) of 18.8 for intermediate wheatgrass, 16.6 for brome, 13.6 for crested wheatgrass, 16.0 for pubescent wheatgrass, and 14.9 for slender wheatgrass, all being higher than the yields of the previous year. Dry matter (herbage mass) yields reported by Lakeland Agricultural Research Association (LARA) for some grasses in Alberta are much lower than those obtained in this study being: between 5.6 and 7.2 (tons ha ${ }^{-1}$ ) for brome, between 3.7 and 4.8 for intermediate wheatgrass, between 1.8 and 2.5 for meadow foxtail (LARA 1994, 1995), between 4.3 and 7.2 (LARA 1995) and 3.2 and 3.7 for timothy (LARA 1993). The differ-

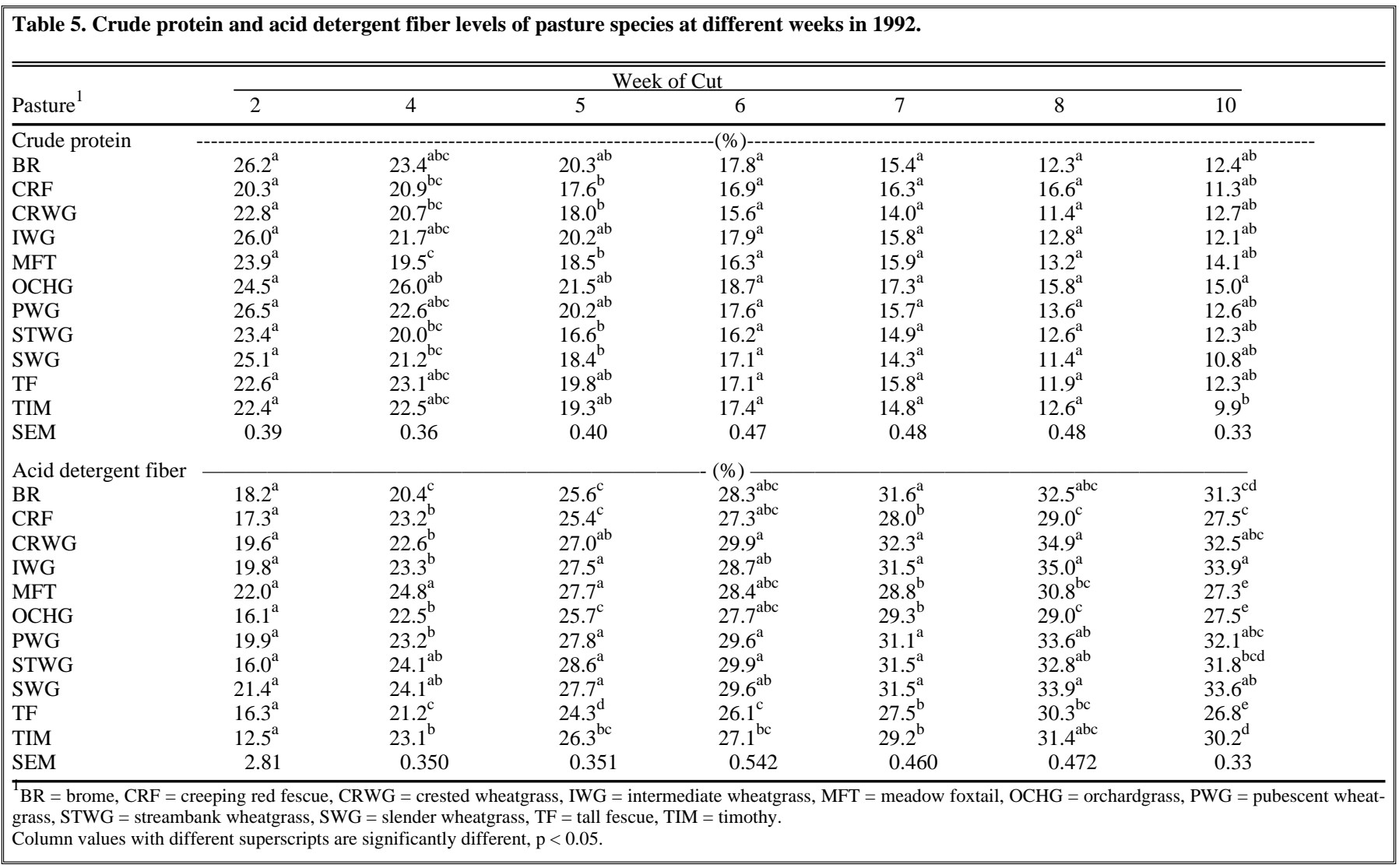




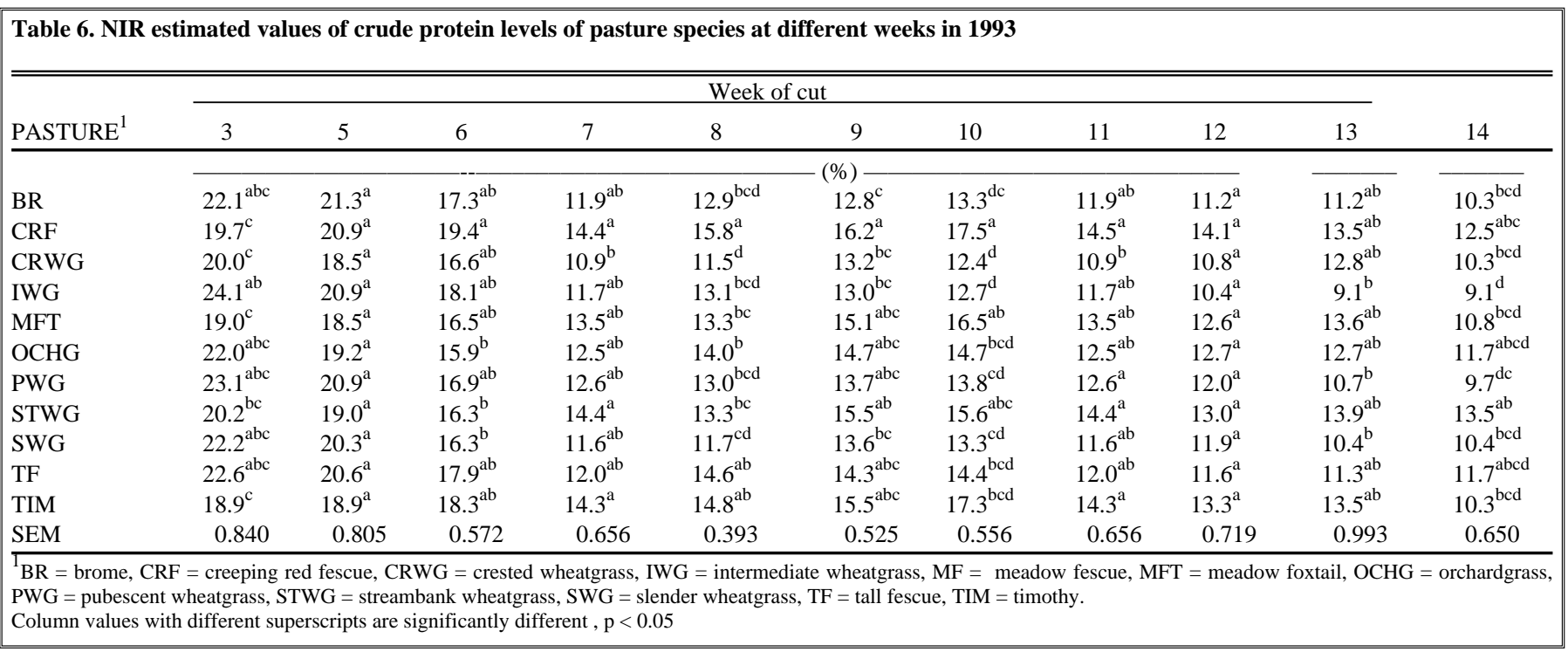

ence in yields may be related to harvest methods. Our yields were higher than some reported yield values because our subsamples were clipped (from $0.25 \mathrm{~m}^{2}$ areas) to a stubble height of $3 \mathrm{~cm}$ compared to stubble height of about $5 \mathrm{~cm}$ described elsewhere for Tall wheatgrass (Undersander and Naylor 1987). Also, in our study, by the end of July (week 9) in 1993 (Table 3), brome, crested wheatgrass and intermediate wheatgrass had, respectively, produced $62 \%$, $66 \%$, and $55 \%$ of their maximum herbage mass yield. In contrast, slender wheatgrass and pubescent wheatgrass produced a significant proportion of herbage mass (49\% and 54\%, respectively), during the latter third of the growing season. This implies that any adverse weather effects during the latter third of the growth period, such as low precipitation, would reduce expected yields in slender wheatgrass and pubescent wheatgrass pastures. Pastures which contain brome as a major component have been shown to result in inadequate forage supplies to meet the growing requirements of the cow and calf (Baron and Knowles 1984).

These results place creeping red fescue as one of the lowest yielding grasses (Table 2) and show streambank wheatgrass to be the lowest yielding wheatgrass in this study, in agreement with an earlier view that it was the lowest yielding cultivated wheatgrass (Smoliak and Bjorge 1981). As well, yields of each crop declined after reaching a maximum (Tables 2 and 3 ). The declines in growth or die back that occurred in 1992, shown by herbage mass yield data at week 10 , could be attributed to the severe effects of drought or senescence caused by self-shading or advanced maturity that apparently ended the growth cycle earlier. The normal growth cycle has been reported to be considerably longer for grasses on the Canadian prairies (Kilcher and Troelsen 1973).

\section{Crude Protein and ADF}

Nutrient composition data of grasses are shown in Tables 5, and 6. As expected, nitrogen content (CP) of the grasses declined as the plant matured (Van Soest 1982). Quality, indicated by $\mathrm{CP}$ and $\mathrm{ADF}$, was highest at first cut, at week 2 (1992) and generally declined in all grasses as the plants matured; and there was an inverse relationship between $\mathrm{CP}$ and $\mathrm{ADF}$ until the yields approached or reached maximum levels (Table 5). Crude protein content of the pastures in 1992 , were initially high but generally decreased or reached a constant level for all grasses as time progressed. The average CP content of grasses declined from $24 \%$ to $13 \%$, the latter value being much higher than $9 \%$ observed elsewhere for brome (Kilcher and Troelsen 1973), indicating an earlier maturing or earlier termination of the growth cycle in this study. The CP content of grasses of between 13 and $24 \%$ falls well within the NRC $(1984,1989)$ range of values considered adequate to meet protein requirement of all classes of grazing cattle (NRC 1984, 1989). However, the ADF content, as is expected with a maturing plant, followed a general pattern of increasing in all grasses with age (Table 5) and, thus, the grasses in this study, as expected, declined in quality as they matured (Van Soest 1982, Kilchner and Troelsen 1973).

The pattern of CP declines as estimated by the NIR procedure in pastures as the plants matured in 1993 was not much different from 1992. From the highest levels initially at week 3, CP content declined in all grasses until week 7 or 8 (Table 6). Thereafter, all forages showed an increase in CP content to week 9 or 10 and followed by, as expected, a pattern of decline in quality, which is a characteristic of maturing plants.

Available information on forages pertains to harvests of pastures or stands that consist of grass mixtures for normal or physiological time frames. Forage composition data in this study were obtained from cumulative harvests at approximately weekly intervals in the growing season (Tables 5-10). This information enhances greater understanding of the effects of maturity on herbage yield and herbage composition of single forage species of cool season grasses in Alberta. Feeding value of the grasses, based on evaluation of the protein and 


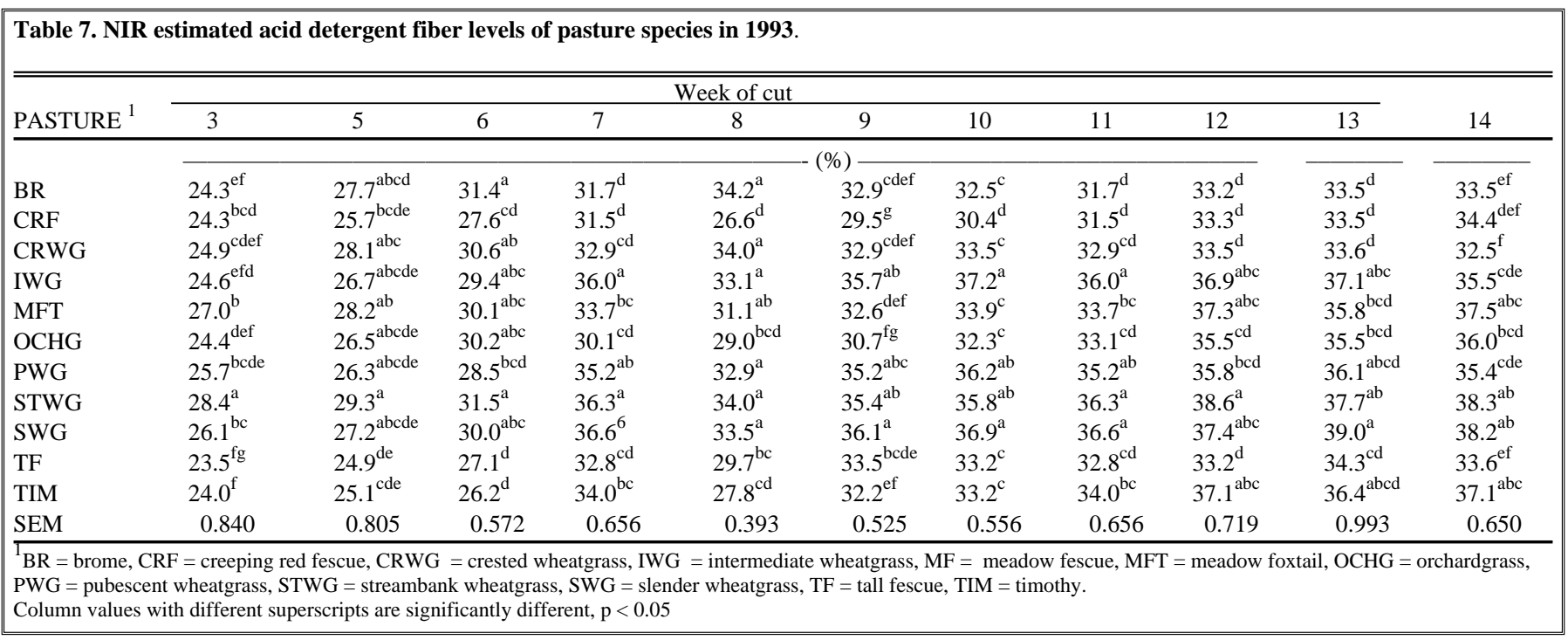

digestible energy content, derived from ADF values (Mathison et al 1982), indicate that the grasses in this study (Tables 5-7), remained, qualitatively, at an 'equivalent' of between the vegetative (grasses at 63\% TDN and $15 \%$ protein content) and boot or bud stage of growth (grasses at $57 \%$ TDN and $11 \%$ protein content) for much of the growing cycle (Smoliak and Bjorge 1981). Such information can be useful in decisions to move cattle into or out of pasture species to extend the grazing season.

\section{Mineral Composition}

Changes in $\mathrm{Ca}$ and $\mathrm{P}$ contents of grasses with increasing maturity in 1992 and 1993 are shown in Tables 8, 9, and 10. All grasses in 1992 reached high $\mathrm{Ca}$ levels of between 0.38 and $0.56 \%$ at week 4 or 5 . Five of the grasses, brome, meadow foxtail, pubescent wheatgrass, streambank wheatgrass, and slender wheatgrass attained $0.38 \% \mathrm{Ca}$ level at the lower end while the 6 remaining grasses reached levels above $0.38 \%$ up to high end level of $0.56 \%$. The $\mathrm{Ca}$ levels in 1992, as the grasses matured, remained adequate for cattle on pasture (NRC 1984,1989). However, the highest $\mathrm{Ca}$ levels of between 0.32$0.44 \%$ (Table 9) were attained much later in the growth cycle of grasses in 1993 (at week 9/10) compared to the grasses in 1992. The maximum levels in 1993 were generally lower than values for 1992 as a result of the comparatively higher forage yields (Table 2 and 3). Calcium levels in all grasses as they matured in 1993 (Table 9), were adequate for cattle on pasture (NRC 1984, 1989).

Phosphorus content of grasses in 1992 varied, from levels of between 0.15 and $0.24 \%$ initially, to between $0.10-0.16 \%$ levels at maximum yield (week 8). The latter levels were low enough to warrant supplementation to meet beef cattle requirement for $\mathrm{P}$ for all grasses with the exception of timothy. Initial P levels, generally higher in 1993 (Table 10) than in 1992, were highest in 1993 for 10 of the 11 grasses (between 0.28 and $0.35 \% \mathrm{P}$ ) (Table

Table 8. Mineral composition of various prairie grasses at different stages of growth in 1992.

\begin{tabular}{|c|c|c|c|c|}
\hline \multirow[b]{2}{*}{ Pasture $^{1}$} & \multicolumn{3}{|c|}{ Week of Cut } & \multirow[b]{2}{*}{10} \\
\hline & 2 & 5 & 7 & \\
\hline \multicolumn{5}{|l|}{ Calcium } \\
\hline BR & $0.34^{\mathrm{a}}$ & $0.38^{\mathrm{a}}$ & $0.29^{\mathrm{e}}$ & $0.32^{\mathrm{d}}$ \\
\hline $\mathrm{CRF}$ & $0.40^{\mathrm{a}}$ & $0.49^{\mathrm{a}}$ & $0.47^{\mathrm{a}}$ & $0.47^{\mathrm{a}}$ \\
\hline CRWG & $0.39^{\mathrm{a}}$ & $0.42^{\mathrm{a}}$ & $0.33^{\text {cde }}$ & $0.35^{\mathrm{bcd}}$ \\
\hline IWG & $0.39^{\mathrm{a}}$ & $0.45^{\mathrm{a}}$ & $0.35^{\mathrm{cd}}$ & $0.35^{\text {bcd }}$ \\
\hline MFT & $0.27^{\mathrm{b}}$ & $0.38^{\mathrm{a}}$ & $0.35^{\mathrm{cd}}$ & $0.40^{\mathrm{bc}}$ \\
\hline OCHG & $0.33^{\mathrm{ab}}$ & $0.38^{\mathrm{a}}$ & $0.35^{\mathrm{cd}}$ & $0.36^{\mathrm{bcd}}$ \\
\hline PWG & $0.32^{\mathrm{ab}}$ & $0.38^{\mathrm{a}}$ & $0.31^{\mathrm{de}}$ & $0.30^{\mathrm{d}}$ \\
\hline STWG & $0.38^{\mathrm{a}}$ & $0.38^{\mathrm{a}}$ & $0.31^{\mathrm{bc}}$ & $0.32^{\mathrm{b}}$ \\
\hline SWG & $0.34^{\mathrm{ab}}$ & $0.38^{\mathrm{a}}$ & $0.31^{\mathrm{de}}$ & $0.32^{\mathrm{d}}$ \\
\hline $\mathrm{TF}$ & $0.38^{\mathrm{a}}$ & $0.46^{\mathrm{a}}$ & $0.41^{\mathrm{b}}$ & $0.42^{\mathrm{b}}$ \\
\hline TIM & $0.33^{\mathrm{ab}}$ & $0.46^{\mathrm{a}}$ & $0.31^{\text {cde }}$ & $0.34^{\mathrm{cd}}$ \\
\hline SEM & 0.016 & 0.027 & 0.13 & .016 \\
\hline \multicolumn{5}{|l|}{ Phosphorus } \\
\hline BR & $0.19^{\mathrm{cd}}$ & $0.17^{\mathrm{bc}}$ & $0.14 b^{c}$ & $0.09^{c}$ \\
\hline CRF & $0.21^{b c}$ & $0.16^{\mathrm{bc}}$ & $0.14 b^{c}$ & $0.10^{\mathrm{c}}$ \\
\hline CRWG & $0.15^{\mathrm{e}}$ & $0.14^{\mathrm{cd}}$ & $0.11^{\mathrm{c}}$ & $0.10^{\mathrm{c}}$ \\
\hline IWG & $0.20^{\text {bcd }}$ & $0.17^{\mathrm{bc}}$ & $0.15^{\mathrm{b}}$ & $0.10^{\mathrm{c}}$ \\
\hline MFT & $0.24^{\mathrm{a}}$ & $0.19^{\mathrm{ab}}$ & $0.15^{\mathrm{b}}$ & $0.12^{\mathrm{b}}$ \\
\hline OCHG & $0.22^{\mathrm{b}}$ & $0.17^{\mathrm{bc}}$ & $0.14^{\mathrm{bc}}$ & $0.11^{b c}$ \\
\hline PWG & $0.19^{\text {bcd }}$ & $0.17^{\mathrm{bc}}$ & $0.14^{\mathrm{bc}}$ & $0.10^{\mathrm{c}}$ \\
\hline STWG & $0.17^{\mathrm{de}}$ & $0.13^{\mathrm{d}}$ & $0.12^{\mathrm{bc}}$ & $0.08^{\mathrm{d}}$ \\
\hline SWG & $0.19^{\mathrm{bcd}}$ & $0.17^{\mathrm{bc}}$ & $0.13^{\mathrm{bc}}$ & $0.10^{\mathrm{c}}$ \\
\hline $\mathrm{TF}$ & $0.20^{\mathrm{bcd}}$ & $0.17^{\mathrm{bc}}$ & $0.14^{b c}$ & $0.10^{\mathrm{c}}$ \\
\hline TIM & $0.24^{\mathrm{a}}$ & 0.21 & $0.18^{\mathrm{a}}$ & $0.14^{\mathrm{a}}$ \\
\hline SEM & 0.007 & 0.008 & 0.006 & 0.004 \\
\hline
\end{tabular}

${ }_{\mathrm{BR}}=$ brome, $\mathrm{CRF}=$ creeping red fescue, $\mathrm{CRWG}=$ crested wheatgrass, $\mathrm{IWG}=$ intermediate wheatgrass, $\mathrm{MFT}=$ meadow foxtail, $\mathrm{OCHG}=$ orchardgrass, $\mathrm{PWG}=$ pubescent wheatgrass, STWG $=$ streambank wheatgrass, $\mathrm{SWG}=$ slender wheatgrass, $\mathrm{TF}=$ tall fescue, $\mathrm{TIM}=$ timothy .

Column values with different superscripts are significantly different, $\mathrm{p}<0.05$. 


\begin{tabular}{|c|c|c|c|c|}
\hline \multirow[b]{2}{*}{ PASTURE $^{1}$} & \multicolumn{4}{|c|}{ Week of cut } \\
\hline & 3 & 7 & 10 & 14 \\
\hline $\mathrm{BR}$ & $0.32^{\text {cde }}$ & $0.31^{\mathrm{b}}$ & $0.32^{\mathrm{de}}$ & $0.30^{\mathrm{c}}$ \\
\hline CRF & $0.39^{\mathrm{a}}$ & $0.43^{\mathrm{a}}$ & $0.43^{\mathrm{a}}$ & $0.39^{\mathrm{a}}$ \\
\hline CRWG & $0.30^{\mathrm{e}}$ & $0.29^{\mathrm{b}}$ & $0.32^{\mathrm{e}}$ & $0.27^{\mathrm{c}}$ \\
\hline IWG & $0.35^{\mathrm{bc}}$ & $0.33^{\mathrm{b}}$ & $0.33^{\mathrm{de}}$ & $0.28^{\mathrm{c}}$ \\
\hline MFT & $0.30^{\mathrm{e}}$ & $0.36^{\mathrm{b}}$ & $0.37^{\mathrm{cd}}$ & $0.35^{\mathrm{b}}$ \\
\hline OCHG & $0.34^{\text {bcd }}$ & $0.31^{\mathrm{b}}$ & $0.32^{\mathrm{de}}$ & $0.34^{\mathrm{b}}$ \\
\hline PWG & $0.34^{\text {bcd }}$ & $0.33^{\mathrm{b}}$ & $0.36^{\text {cde }}$ & $0.29^{\mathrm{c}}$ \\
\hline STWG & $0.32^{\text {cde }}$ & $0.34^{\mathrm{b}}$ & $0.40^{\mathrm{b}}$ & $0.34^{\mathrm{b}}$ \\
\hline SWG & $0.32^{\text {cde }}$ & $0.28^{\mathrm{b}}$ & $0.31^{\mathrm{e}}$ & $0.28^{\mathrm{c}}$ \\
\hline $\mathrm{TF}$ & $0.34^{\mathrm{bc}}$ & $0.35^{\mathrm{b}}$ & $0.37^{\mathrm{c}}$ & $0.35^{\mathrm{b}}$ \\
\hline TIM & $0.30^{\mathrm{e}}$ & $0.31^{\mathrm{b}}$ & $0.35^{\text {cde }}$ & $0.27^{\mathrm{c}}$ \\
\hline SEM & 0.006 & 0.015 & 0.011 & 0.01 \\
\hline \multicolumn{5}{|c|}{$\begin{array}{l}\mathrm{BR}=\text { brome, } \mathrm{CRF}=\text { creeping red fescue, } \mathrm{CRWG}=\text { crested wheatgrass, } \mathrm{IWG}=\text { intermediate wheatgrass, } \mathrm{MFT}= \\
\text { meadow foxtail, } \mathrm{OCHG}=\text { orchardgrass, } \mathrm{PWG}=\text { pubescent } \text { wheatgrass, } \mathrm{STWG}=\text { streambank wheatgrass, } \mathrm{SWG}= \\
\text { slender wheatgrass, TF }=\text { tall fescue, } \mathrm{TIM}=\text { timothy. } \\
\text { Column values with different superscripts are significantly different, } \mathrm{p}<0.05 .\end{array}$} \\
\hline
\end{tabular}

10), while 4 grasses (creeping red fescue, meadow foxtail, streambank wheatgrass and timothy) had maximum P levels at week 10. Phosphorus levels decreased in all grasses to between 0.12 and $0.31 \%$ at maximum yield (week 12). In 1993, P levels in brome, crested wheatgrass, intermediate wheatgrass, and pubescent wheatgrass were low enough to require supplementation to meet the requirements of beef cattle (Table 10).

\section{Application of NIRS Technology to Predict Composition of Grasses}

Values of standard error of calibration (SEC), the slope and $\mathrm{r}^{2}$ obtained on calibration samples for each nutrient for the years 1992 and 1993 and 1992 \& 1993 combined are shown in Table 10. Accuracy of prediction of chemical composition of grasses in this study compares favourably with other researchers. Our SEC value of $0.46 \%$ for CP compares closely with $1.0,1.07,0.95,0.90$ and 0.7 to $1.1 \%$ SE values obtained with scanning instruments by Norris et al. (1976), Shenk et al. (1979) and Marten et al. (1983) Redshaw et al. (1986), respectively. Similarly, SE of $0.61 \%$ for ADF prediction is lower than the value of $1 \%$ SE's obtained by Norris et al. (1976), Shenk et al. (1979, 1981) and Marten et al. (1983) and is a third the $2.0 \%$ SE value obtained by Redshaw et al. (1986). The improve-

$0.05 \%$ compares favourably with a range of $\mathrm{Ca}$ determinations from 0.14 to $0.22 \%$ (Redshaw et al. 1986, Shenk et al.1979, 1981). Similarly, SE for P was $0.02 \%$ compared to between 0.02 and $0.04 \%$ in the other papers. In addition, the validation statistics of the regressions, such as the high $\mathrm{r}^{2}$ values of 0.90 and slope of 0.88 or higher for CP, P, ADF and DM for 1992, 1993 and 1992 and 1993 combined indicate that the grass calibrations developed are excellent (Hsu et al. 1997, Shenk and Westerhaus 1991a, 1991b, 1991c; Shenk et al.1993). Except for Ca, the $r^{2}$ values obtained between actual and predicted for the grasses in 1992 and combined validation sets were 0.99 vs $1.00(\mathrm{DM}), 1.01$ vs $0.99(\mathrm{CP}), 0.55$ vs $0.59(\mathrm{Ca}), 0.88$ vs $0.90(\mathrm{P})$ and 0.97 vs 0.98 (ADF). The SEC's were 0.09(DM), 0.56(CP), 0.91(ADF), $0.06(\mathrm{Ca})$, and $0.03(\mathrm{P})$ on data from the first year. Combining data from the 2 years improved the fit (Table 1). Overall mean values from NIRS prediction compared to wet chemistry analyses were $94.28,94.28$ for DM, $16.78,16.80$ for CP, 29.83, 29.84 for ADF, 0.35, 0.35 for $\mathrm{Ca}$ and $0.19,0.19$ for $\mathrm{P}$, respectively. These data suggest a great potential for the application of NIRS calibrations in the analysis of nutrient composition of grasses, regardless of the stage of growth at harvest, because the procedure is capable of generating reliable results quickly.

\section{Conclusions}

Yield information on grasses as the plant matures is considered useful in optimizing grazing potential and quality hay production. Herbage mass yields $\left(\mathrm{g} / 0.25 \mathrm{~m}^{2}\right)$ of selected prairie grasses were similar for the grass species for both years, except for crested wheatgrass in 1992 and brome in 1993. Most grasses reached maximum yields at week 8 in 1992 (drought year) and week 12 in 1993 (a more normal year). Quality declined

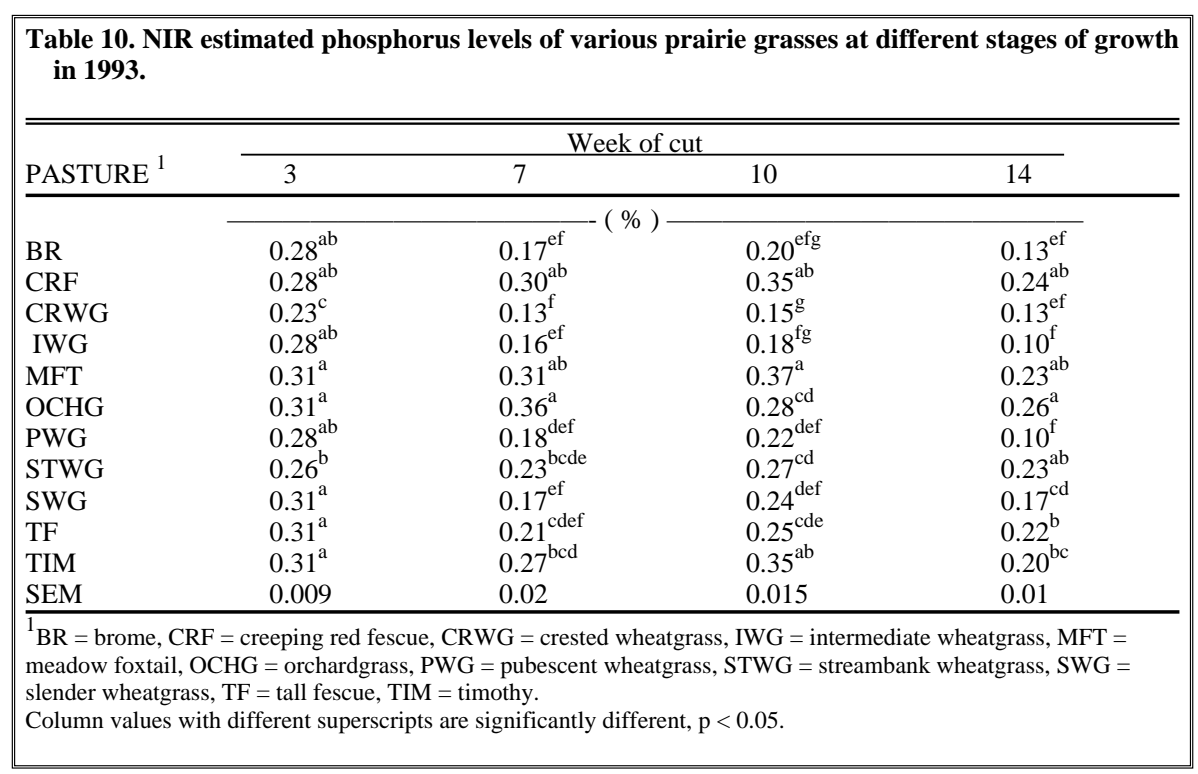


in all grasses as they matured. There was an inverse relationship between $\mathrm{CP}$ and ADF until the yields approached maximum levels. The average $\mathrm{CP}$ content of grasses declined from $24 \%$ to $13 \%$ in 1992 and from $21.5 \%$ to $12.1 \%$ in 1993 ; however, these levels were adequate to meet protein requirements of grazing cattle. Based on both years' data, the 5 high yielding grasses identified were intermediate wheatgrass, brome, crested wheatgrass, pubescent wheatgrass, and slender wheatgrass. The $\mathrm{Ca}$ levels in all grasses were adequate for cattle on pasture but the low $\mathrm{P}$ levels near $0.10 \%$ (at week 8) in 1992 and $0.12 \%$ (at week 12) in 1993, indicate that cattle on such pastures would require $P$ supplementation. With the exception of $\mathrm{Ca}$, NIRS regression statistics obtained on all grasses yielded low values of standard error of calibration, $\mathrm{r}^{2}$ values higher than 0.90 and slopes of actual vs predicted at 0.88 or higher for $\mathrm{CP}, \mathrm{P}, \mathrm{ADF}$, and DM determinations.

These results strongly show that the calibrations developed for grasses in Alberta are acceptable. Thus, NIRS technology can be used to rapidly and accurately analyse for dry matter, crude protein, acid detergent fiber, calcium, and phosphorus in grasses at different stages of growth in Alberta. Addition of more data into the calibrations can only result in improved analysis and application of this technology in forage systems in Alberta.

\section{Literature Cited}

AOAC Official Methods of Analysis. 1990. (15th Ed.). Association of Official Analytical Chemists, Arlington, Virg.

Baron, V.S. and R.P. Knowles. 1984. Use and improvement of meadow brome as a pasture species for Western Canada. Proc. 2nd intermountain meadow symposium. Special Series \#34 Colorado State Univ. and Univ. of Wyoming Agr. Exp. Stations.

Bowser, W.E., A.A. Kjearsgaard, T.W. Peters and R.E. Wells. 1962. Soil survey of Edmonton sheet (83-HO). Univ. of Alberta Bull. No. SS-4, Alberta Soil Survey Rep. No. 21. Univ. Of Alberta Press, Edmonton, AB.
Goering, H.K. and P.J. Van Soest. 1970. Forage fiber analyses (apparatus, reagents, procedures, and some applications). Agr. Handb. No.379. ARS, USDA, Wash., DC.

Hsu, H., A. Suleiman, and G. RecinosDiaz. 1997. Potential Use of Near Infrared Reflectance Spectroscopy for Determining Protein Fractions in Forages. Farming For the Future Rep, Project \#94-0521, Edmonton, AB., Canada.

Kilchner, M.R. and J.E. Troelsen. 1973. Contribution of stems and leaves to the composition and nutrient content of irrigated bromegrass at different stages of development. Can. J. Plant Sci. Vol.53.

Lakeland Agricultural Research Association 1993 Annual Report. Grasses Section, Box 7068, Bonnyville, AB., Canada. T9N 2H4.

Lakeland Agricultural Research Association 1994 Annual Report. Grasses Section, Box 7068, Bonnyville, AB., Canada. T9N $2 \mathrm{H} 4$.

Lakeland Agricultural Research Association 1995 Annual Report. Grasses Section, Box 7068, Bonnyville, AB., Canada. T9N $2 \mathrm{H} 4$.

Marten, G.C., J. L. Halgerson, and J.H. Cherney. 1983. Quality prediction of small grain forages by near infrared spectroscopy. Crop Sci. 23:94-96.

Mathison, G.W., P.M. Kennedy, L.P. Milligan and R.D. Weisenburger. 1982. 'Ruminant Feed Evaluation Unit', The 61st Annual Feeders' Day Report, Agr. and Forestry Bull., Univ. of Alberta, Edmonton. AB., Canada.

McCaughey, W.P. and R.L. Cliplef. 1996. Carcass and organoleptic characteristics of meat from steers grazed on alfalfa/grass pastures and finished on grain. Can. J. Anim. Sci. 76:149-152.

National Research Council, 1984. Nutrients Requirements of Beef Cattle. Sixth ed. Nat. Acad. Press, Washington, D.C.

National Research Council, 1989. Nutrients Requirements of Beef Cattle. Sixth ed. Nat. Acad. Press, Washington, D.C

Norris, K.H., R.F. Barnes, J.E. Moore, and J.S. Shenk. 1976. Predicting forage quality by infrared reflectance spectroscopy. J Anim. Sci. 43:889-897.

Redshaw,E.S., G.W. Mathison, L.P. Milligan, and R. D. Weisenburger. 1986. Near infrared reflectance spectroscopy for predicting forage compositon and voluntary consumption and digestibility in cattle and sheep. Can. J. Anim. Sci. 66: 103-115.

SAS (Statistical Analysis System) 1990. SAS/STAT User's Guide. SAS Institute, Inc., Cary, N.C.
Shenk, J.S. 1989. Analysis of forage quality in Near Infrared Reflectance Spectroscopy (NIRS), G.C Marten, F.E. Barton II , and J.S. Shenk, Ed. USDA Agr. Handb. No. 643.Shenk, J.S. and M.O. Westerhaus. 1991a. Population definition, sample selection and calibration procedures for near infrared reflectance spectroscopy. Crop Sci. 31:469-474.

Shenk, J.S. and M.O. Westerhaus. 1991b. Population structuring of near infrared spectra and modified partial least squares regression. Crop Sci.31:1548-1555.

Shenk, J.S. and M.O. Westerhaus. 1991c. New standardization and calibration procedures for NIRS analytical system. Crop Sci.31:1694-1696.

Shenk, J.S. and M.O. Westerhaus. 1994. The application of NIRS to forage analysis. In Forage Quality Evaluation and Utilization. Fahey, G.C.,Jr.(Ed). Amer.Soc. of Agron., Crop Sci. Soc. and Soil Sci. Soc. of Amer., Madison, Wisc. pp. 406- 449.

Shenk, J.S., M.O.Westerhaus and M.R. Hoover. 1979. Analysis of forages by infrared reflectance. J. Dairy Sci. 62: 807-812.

Shenk, J.S., J.J. Workman, and M. O. Westerhaus. 1993. Application of NIR Spectroscopy to Agricultural Products. In Handbook of Near-Infrared Analysis. Burns, Donald. A and Emil W. Ciurczak (Ed.). Marcel Dekker, Inc. N. Y. pp 383429.

Shenk, J.S., I. Landa, M.R. Hoover, and M.O. Westerhaus. 1981. Description and evaluation of a near infrared reflectance spectro-computer for forage and grain analysis. Crop Sci. 21:355-358.

Smith, L. 1981. Economics of feeding cattle in north-central and northern Alberta. Alberta Agr. Agdex 821-10.

Smoliak, S., and M. Bjorge. 1981. Hay and Pasture Crops in Alberta Forage Manual. Alberta Agr. Agdex 120/ 20-4.

Van Soest, P.J. 1982. Nutritional ecology of the ruminant. O \& B Books, Inc. Corvalis, Ore.

Undersander, D.J. and C.H. Naylor. 1987. Influence of clipping frequency on herbage yield and nutrient content of tall wheatgrass. J. Range Manage. 40:31-34. 